This is an electronic reprint of the original article. This reprint may differ from the original in pagination and typographic detail.

Author(s): Clements, Kati; Pawlowski, Jan; Manouselis, Nikos

Title: $\quad$ Open educational resources repositories literature review - Towards a comprehensive quality approaches framework

Year: $\quad 2015$

Version:

Please cite the original version:

Clements, K., Pawlowski, J., \& Manouselis, N. (2015). Open educational resources repositories literature review - Towards a comprehensive quality approaches framework. Computers in Human Behavior, 51, Part B, 1098-1106. https://doi.org/10.1016/j.chb.2015.03.026

All material supplied via JYX is protected by copyright and other intellectual property rights, and duplication or sale of all or part of any of the repository collections is not permitted, except that material may be duplicated by you for your research use or educational purposes in electronic or print form. You must obtain permission for any other use. Electronic or print copies may not be offered, whether for sale or otherwise to anyone who is not an authorised user. 


\title{
OPEN EDUCATIONAL RESOURCES REPOSITORIES LITERATURE REVIEW - TOWARDS A COMPREHENSIVE QUALITY APPROACHES FRAMEWORK
}

\author{
Kati Clements ${ }^{1}$, Jan Pawlowski ${ }^{2}$, Nikos Manouselis ${ }^{3}$ \\ ${ }^{1}$ University of Jyväskylä, Mattilanniemi 2, 40014 Jyväskylän yliopisto, Finland. \\ kati.clements@jyu.fi(FINLAND) \\ ${ }^{2}$ Ruhr West University of Applied Sciences, Informatics Institute, Mülheim, Germany \\ jan.pawlowski@hs-ruhrwest.de (GERMANY) \\ ${ }^{3}$ Agro-Know Technologies, 17 Grammou Str., Vrilissia, 15235, Athens nikosm@ieee.org \\ (GREECE)
}

\begin{abstract}
Today, Open Educational Resources (OER) are commonly stored, used, adapted, remixed and shared within Learning object repositories (LORs) which have recently started expanding their design to support collaborative teaching and learning. As numbers of OER available freely keep on growing, many LORs struggle to find sustainable business models and get the users' attention. Previous studies have shown that Quality assurance of the LORs is a significant factor when predicting the success of the repository. Within the study, we analysed technology enhanced learning literature systematically regarding LORs' quality approaches and specific collaborative instruments. This paper's theoretical contribution is a comprehensive framework of LOR quality approaches (LORQAF) that demonstrates the wide spectrum of possible approaches taken and classifies them. The purpose of this study is to assist LOR developers in designing sustainable quality assurance approaches utilizing full the potential of collaborative quality assurance tools.

Keywords: Open Educational Resources, Collaborative learning environments, Computer Supported Collaborative Learning, Learning object repositories, Quality assurance, Literature review
\end{abstract}




\section{Introduction}

For the last two decades, a rapidly growing amount of Open Educational Resources (OER) has become available in Learning objects repositories (LORs) for educators to re-use, republish and share within their communities, supporting collaborative learning (Dimitriadis et al., 2009). Smaller OER repositories are built into federated repositories by being harvested for their metadata to improve access to higher numbers of learning objects (Tzikopoulos et al., 2007). Unfortunately, these repositories are not used up to their full potential (Ochoa \& Duval, 2009; Mitchell \& Lutters, 2006; Dichev \& Dicheva, 2012). Thousands of digital resources are created collaboratively and published online every day, and their quality control, assurance and evaluation are of paramount importance for potential users (Downes, 2007; Palavitsinis et al., 2013). OER enable forms of collaborative learning (Dillenbourg, 1999) and LORs of today can be considered as computer supported collaborative learning (CSCL) environments as they provide users tools for posting knowledge productions into a shared working space and providing tools for progressive discourse interaction between the users (Scardamalia \& Bereiter, 1994). Adding social and collaborative features has been a recent trend of LORs to facilitate wider user engagement (Monge et al., 2008; Sánchez-Alonso et al., 2011).

According to previous studies (Barton et al., 2003; Attwell, 2005; Clements \& Pawlowski, 2012) quality of OER plays a significant role in the success of the open content repositories (LOR) (Tate \& Hosek, 2009; Cechinel et al., 2011). Therefore, it is vital to study LORs quality approaches (Clements et al., 2014) in a systematic way. Previous literature reviews on LOR quality approaches have focused on metadata quality only (Palavitsinis et al., 2013) and in the case of Atenas and Havemann (2014) have defined quality approaches quite simply as any approach which might attract users' to re-use content. However, this is the first systematic LOR quality approaches literature review which looks at quality management as a holistic approach around the repository, not only focusing on the quality instruments but also policies, standardization and pre-publication related quality approaches. This literature review puts emphasis towards collaborative tools such as peer review (Neven \& Duval, 2002), which contribute towards the quality assurance of the repository. CSCL is an emerging research field that focuses on how collaborative learning, supported by technology, can enhance peer 
interaction and work in groups, and how collaboration and technology facilitate sharing and distributing knowledge and expertise among community members (Lipponen et al., 2004).

Learning object repositories quality approaches have previously been classified as (Pawlowski \& Clements, 2010):

1. The Generic Approach of Quality standards (e.g. ISO 9000 standards (Stracke, 2009), European Foundation for Quality Management Excellence (EFQM, 2014)

2. Specific Quality Approaches (e.g. Content development criteria or competency requirements) (Leacock \& Nesbit, 2007)

3. Specific Quality Instruments (e.g. user generated collaborative quality approaches such as rating (Nesbit et al., 2002), peer review (Neven \& Duval, 2002) or recommender systems (Manouselis et al., 2014)

In this study, we investigated quality approaches for LORs with a systematic literature review (Kitchenhamn, 2004) in order to understand the holistic phenomenon of quality assurance comprehensively and to form a quality approaches framework which LOR developers can take into account when designing new repositories as well as improving the quality of the existing ones. The classification above was used to guide our review process as the starting theoretical framework.

This paper is organized as following: In the second section, we describe the main concepts of educational resources and learning object repositories. In the third chapter we define quality approaches around repositories. Chapter four describes the literature review methodology and systematic mapping of quality approaches. Chapter five presents the analysis of the results and the learning object repositories quality assurance framework (LORQAF). The paper concluded with a summary of results clarifying the contributions of this study for theory and practice.

\section{Theoretical background}

\subsection{Open Educational Resources}

Downes (2007) describes Open Educational Resources (OER) as: "In the system implemented by Creative Commons (widely thought to be representative of an "open" license) authors may 
stipulate that use requires attribution, that it be non-commercial, or that the product be shared under the same license. According to Wiley \& Edwards (2002) a learning object is "any digital resource that can be reused to mediate learning." OECD's (2007) definition was: "Open educational resources are digitized materials offered freely and openly for educators, students and self-learners to use and reuse for teaching, learning and research". Very popular definition of OER is by UNESCO (2002) defining OER as "technology-enabled, open provision of educational resources for consultation, use and adaptation by a community of users for non-commercial purposes". Davis \& al. (2010) described educational resources as sets of resources, which have been assembled and described with the intention that they could be picked up and re-used by others. Harmonizing the previous definitions, this study defines OER as "All resources for the purpose of learning, education and training which are freely accessible for the user". In the context of this paper, we recognize that educational resources' synonyms from the technology enhanced learning literature include: 'learning objects, digital resources, digital content, digital resources, reusable learning objects, educational objects, educational resources and educational content'. Digital resources can be shared, re-used and collaboratively created across different countries and cultures (Laurillard, 2008). Open educational resources can support collaborative learning particularly well because they have been designed to be enhanced and repurposed and therefore can support cognitive processes behind collaborative learning (Dimitriadis et al., 2009). OER also provide opportunities for long term collaboration and partnerships beyond people's daily context (Pirkkalainen et al., 2014a).

OER's significant milestone in its history was MIT's OpenCourse Ware Initiative (Albelson, 2008) where large amount of courses were made freely available. After MIT's example, many institutions have followed the policy of giving out course materials for free - selling the diplomas or graduation certificates. This way OER can work as a marketing tool for the institute's recruitment. OER certainly have been accepted in the community, but face the common problems of the $21^{\text {st }}$ century: Information is in such large quantities - how to get the teachers' attention towards these materials? In order for OER to be re-used, they have been most commonly gathered into databases that are linked to a user interface portal. This is called a Learning object repository. 


\subsection{Learning Object Repositories}

LOR are multi-functional platforms which are designed to facilitate access to reusable learning objects in a variety of formats, so users can search for, find and make use of this content (Downes, 2001). Learning object repositories can also be defined as digital databases that house learning content, applications and tools such as texts, papers, videos, audio recordings, multimedia applications and social networking tools (McGreal, 2011). The purpose of a repository is not simply safe storage and deliver resources, but allow their administration in terms of updating, identifying, utilizing, sharing and re-using them (Retalis, 2005). OER creation also provides potential for teachers and educators for co-creation and collaboration, which are processes that state-of-the-art LORs try to support through social networking features (Okada et al., 2012). Although such LORs using social software for collaborative learning and teaching raise barriers for users in areas like cultural distance and lack of quality (Pirkkalainen et al, 2014b). Some popular examples of LORs include: Le Mill $^{1}$, OER Commons ${ }^{2}$ and KlasCement ${ }^{3}$.

McGreal (2008) classifies learning object repositories into three basic types:

1. Centralized model with content stored on the site

2. Portals that mainly store links and metadata to materials provided by others

3. Repositories with equal role as a content provider and portal

McGreal's (2008) study has been widely used as it identified the principal functionalities of LORs as: search/browse OER, view OER, download OER, store OER and download OERs metadata.

Another type of classification is based on the nature of the content and content providers: Learning object repositories might contain resources from a certain topic (thematic repository). Many ministries of education have their own nation-wide portals for all topics (National repository). LORs which harvest metadata from other repositories are called 'Federated repositories'. (Clements et al., 2014)

\footnotetext{
${ }^{1} \mathrm{http}: / /$ lemill.net/

$2 \mathrm{https} / / /$ www.oercommons.org/

${ }^{3} \mathrm{http}: / / w w w . k l a s c e m e n t . b e /$
} 
General characteristics of well known LORs were studied by Tzikopoulos, Manouselis, and Vuorikari (2009). Their investigation covered features such as educational subject areas covered, metadata, standard used, LOs availability in different languages, quality control, evaluation mechanisms and intellectual property management. This study provided an overview about LORs' current development status and popular features that they incorporate.

Ochoa and Duval (2009) provided a comprehensive quantitative analysis of LORs' growth and usage, in which was discouraging to notice that LORs struggle to keep their users coming back to them, specifically if they were built on project funds - many have trouble extending their community after the initial funding ends.

In a recent study, Zervas et al., (2014) analysed 49 major repositories functionalities, but also published the details of common repositories' user and content amounts. Most project built repositories don't seem to reach the masses of users and their user base remains in a few thousand. In Zervas et al.'s analysis, only two repositories reached over a 100000 users, Merlot $^{4}$ (118.874 users) and Curriki ${ }^{5}$ (387.189 users). By far the biggest amount of learning objects are within the federated repository system of Ariadne ${ }^{6}$ (830.297 LOs). Information was from February 2014. This study also found out that current LORs' implementation adopts mainly functionalities that are related to the basic functionalities of LORs, whereas functionalities related to the added value services (such as social collaboration tools as well as evaluation tools) component are limited. This provided us with evidence that current LORs are mainly developed for facilitating the storage and retrieval of LOs, whereas functionalities for facilitating collaboration between teachers and learners when using LOs available in LORs are rarely supported, even though repositories have for quite some time already been trying to move towards supporting collaborative learning (Monge et al., 2008). Previous studies have observed that LORs oriented towards the generation of content should also consider quality assessment and not just constrained to content and furthermore, being opened to the entire process of collaborative construction of new knowledge (Pérez-Mateo et al., 2011).

\footnotetext{
${ }_{5}^{4} \mathrm{http} / / / \mathrm{www} . \mathrm{merlot} .0 \mathrm{rg} / \mathrm{merlot} / \mathrm{index} . \mathrm{htm}$

${ }^{5} \mathrm{http}: / /$ www.curriki.org/

${ }^{6} \mathrm{http}: / /$ www.ariadne-eu.org/
} 


\section{Quality approaches for LORs}

Quality can mean different things to different people in different contexts (Clements et al., 2014). We should study quality as a phenomenon, which is part of a given community of practice and a specific product (Ochoa \& Duval, 2009). ISO 9000 (2014) standard defines quality as the totality of features and characteristics of a product or service that bear on its ability to satisfy stated or implied needs. Quality can also be defined as "[...] appropriately meeting the stakeholders' objectives and needs which is the result of a transparent, participatory negotiation process within an organization." (Pawlowski, 2007). In the context of OER and LORs quality can for example mean that teacher finds a suitable resource for his/her teaching.

LORs typically have significant problems with the quality of the resources (Pawlowski \& Zimmermann, 2007; Pérez-Mateo et al., 2011). Previous studies on LOR have highlighted the issue of quality assurance of repositories, as this is seen as key to provision of quality content to end users (Manouselis \& Costopoulou, 2006; Petrides et al., 2008; Atenas \& Havemann, 2014). In this study we look at the quality of LORs not only from the perspective of the quality of the OER, but from the perspective of the repository and the services around it.

Quality approaches classification (Clements \& Pawlowski, 2012) is presented in table 1.

\begin{tabular}{|c|c|c|}
\hline Approach & Purpose & Examples \\
\hline $\begin{array}{l}\text { Generic } \\
\text { quality } \\
\text { approaches }\end{array}$ & $\begin{array}{l}\text { Quality standards present } \\
\text { concepts for quality } \\
\text { management, independent of } \\
\text { the domain of usage }\end{array}$ & $\begin{array}{l}\text { ISO 9000:2000 (ISO, 2014) } \\
\text { EFQM (EFQM, 2014) }\end{array}$ \\
\hline $\begin{array}{l}\text { Specific } \\
\text { Quality } \\
\text { approaches } \\
\text { for TEL } \\
\text { domain }\end{array}$ & $\begin{array}{l}\text { Quality management or } \\
\text { quality assurance concepts } \\
\text { for the field of learning, } \\
\text { education, and training, top- } \\
\text { down approach }\end{array}$ & $\begin{array}{l}\text { QAA Framework Consortium for } \\
\text { Excellence in Higher Education (Higher } \\
\text { Education Founding Council for England, } \\
\text { 2001) } \\
\text { Quality criteria (Pérez-Mateo et al., 2011) }\end{array}$ \\
\hline $\begin{array}{l}\text { Specific } \\
\text { quality }\end{array}$ & $\begin{array}{l}\text { User generated quality } \\
\text { mechanisms for managing }\end{array}$ & $\begin{array}{l}\text { Ratings (Nesbit et al., 2002) } \\
\text { Recommender Systems (Manouselis et al., }\end{array}$ \\
\hline
\end{tabular}




\begin{tabular}{|l|l|l|}
\hline instruments & $\begin{array}{l}\text { specific aspects of quality, } \\
\text { bottom-up approach }\end{array}$ & $\begin{array}{l}\text { 2013) } \\
\text { Peer reviews (Neven \& Duval, 2002) } \\
\text { Trusted networks approach (Clements \& } \\
\text { Pawlowski, 2012) }\end{array}$ \\
\hline
\end{tabular}

Table 1: Quality classification (Clements et al., 2013)

\subsection{Generic quality approaches}

Generic quality approaches provide quality management or quality assurance procedures independent of the domain. When applied to a certain domain (such as Technology Enhanced Learning or OER), these approaches need to be extended and adapted. Generic approaches contain domain-independent quality approaches and can generally lead to trust in certified organizations. If an organization uses for example the EFQM excellence model, it is assured that all products have been assessed and quality controlled. From a user's point of view, this means that the trust in organizations and thus their products can be increased. While the EFQM-Model is used for self-assessment, the ISO 9000 is used to prove organizations by external assessment to earn a seal of approval (Ehlers \& Pawlowski, 2004).

\subsection{Specific quality approaches}

Specific quality approaches provide quality assurance procedures for the domain of Technology Enhanced Learning. Specific approaches aim at achieving high quality of certain products, e.g. at OER and related technologies. By applying certain quality approaches, also here a minimum quality is achieved. Specific quality approaches differ in scope and methodology, ranging from quality marks for education (Pawlowski, 2007) to content development criteria (Leacock \& Nesbit, 2007) or competency requirements (Ehlers, 2009).

Specific quality approaches also include outsourcing the evaluation of the OER for external experts (Nielsen, 1994). This might be the most reliable way of judging OER quality, however most LORs do not have a sustainable way of hiring experts, which is why they rely on specific quality instruments which bring in quality assurance through crowd sourcing.

\subsection{Specific quality instruments}

Not all problems of quality can be addressed effectively by machine solutions (Barton et al., 2003). Specific quality instruments (Pawlowski \& Clements 2010; Atenas \& Havemann, 
2014; Hylen, 2006) are commonly known as technological features in the repositories, through which the community of users generate their own quality assurance either directly (rating, reviewing, commenting, flagging etc.) or indirectly (The LOR portal can monitor the users' activities and based on that social data, make automatic promotions of content (recommendation systems). Vargo et al., (2003) proposed an evaluation instrument called "LORI" for peer reviewing and commenting on learning objects. LORI (version 1.3) included the measures 10 separate qualities of learning objects including:

1. Presentation: aesthetics

2. Presentation: design for learning

3. Accuracy of content

4. Support for learning goals

5. Motivation

6. Interaction: usability

7. Interaction: feedback and adaptation

8. Reusability

9. Metadata and interoperability compliance

10. Accessibility

As OER repositories need sustainable solutions for quality assurance (Downes, 2007), specific quality collaborative instruments have become increasingly popular. Unfortunately, in voluntary settings in OER communities, it is not easy to find adequate motivated reviewers unlike in fields like e-commerce. Specific quality instruments can only work with a strong community behind them (Davis et al., 2010). LOR developers favour specific quality collaborative instruments because they are cost-effective, however, they are problematic also because of the context nature of quality.

\section{Methodology}

This study is motivated by the following objective: To perform a systematic literature review on quality approaches and success measuring of learning object repositories. The goal of the analysis was to answer the following research questions:

1. What kind of approaches \& instruments do learning object repositories use for managing their quality?

2. How to classify quality approaches for LORs?

3. Which kinds of characteristics do the approaches have? 
The literature review for the quality approaches was conducted using the systematic approach by Fink (2005) as method to describe available knowledge for professional practice. The rigorous approach should be systematic with clear methodology, explicit in the procedures, comprehensive in the analysis and reproducible by others (Fink, 2005). The literature review followed the steps defined by Kitchenham (2004) for conducting a rigorous analysis. The steps include: (1) Identify need and define the method, (2) create research question(s), (3) conduct the search for relevant literature, (4) assess the quality and appropriateness of the studies, (5) extract data from the studies, (6) conduct data synthesis and finally (7) interpret the results and write a report.

During the literature analysis, we used synonyms of OER and LORs (defined in chapter 2) in order to identify as many studies in the field as possible. This allowed us to have a better overall scope of the approaches as the varied terminology is often used to express the same phenomenon. For all of the key literature, the main entry points were IEEE Xplore bibliographic database, ACM Digital Library as well as Google scholar. A total of 82 papers from 1994 to 2014 were included in the final analysis for the quality approaches in the field of Technology Enhanced Learning. Most papers focus on the recent 5 years of research. Currently the oldest learning object repositories are starting to be about 17 years old (Zervas et al., 2014), which makes this the correct period to analyze also the studies on them.

The synthesis part of the literature review takes a constructive approach (Crnkovic, 2010). Constructive research is suitable for construction of a solution (artifact or a theory) that is based on existing knowledge (Crnkovic, 2010). In our case the approach is to build on existing knowledge on quality approaches and to construct an artifact in form of a framework in order to study the quality approaches for LORs. Therefore, the conceptual framework is aimed towards theory building (Nunamaker, Chen, and Purdin, 1990) by contributing to the body of knowledge with a variety of challenges that require validation in real stakeholder contexts.

The constructive part is combined with the approach of Kitchenham (2004) by analyzing, synthesizing and interpreting the literature in order to finalize the data analysis and construct the quality assurance framework. 


\section{Quality approaches - a critical analysis of current literature}

This section describes how quality approaches have been studied in Technology enhanced learning field. As the main result, our study synthesizes the findings by introducing the Learning object repositories quality assurance framework (LORQAF). To better explain the quality assurance process and actors, we synthesized the data in order to classify the identified quality approaches in the Learning object repositories quality assurance framework LORQAF. This framework will serve as a holistic approach for understanding the overall picture of LORS quality approaches. LORQAF is presented in Figure 1.

\section{Learning Object Repositories Quality Assurance Framework (LORQAF)}

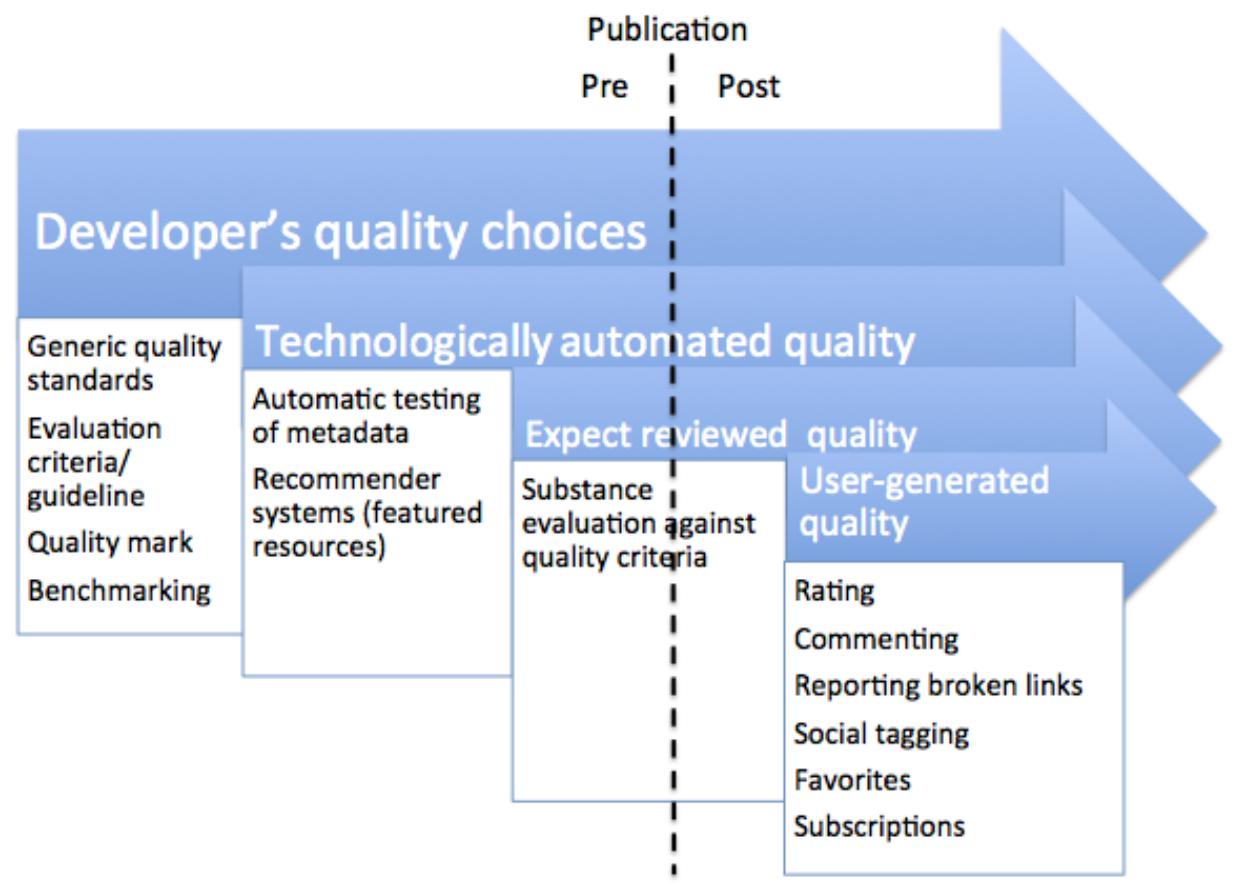

Figure 1. Learning object repositories quality assurance framework (LORQAF)

During the data extraction phase (Kitchenham, 2004), we found out that quality assurance strategies often are a combination of many choices made by the LOR developer: Which standards to use, which evaluation criteria to select, which tools to give out to the community. For the sake of discussing the variety of quality approaches we will harmonize the approaches to categories according to the quality assurance classification of table 1. For example a technology developer can set automated recommender systems to give out featured resources 
to the users, but the recommendation algorithms are often based on users' actions in the repository portal, which means that the only through a powerful community can the recommender system approach succeed. Many quality approaches are operationalized before publishing the educational resources, however, quality assurance is an on-going process and most repositories offer both technological as well as user-generated collaborative quality instruments. In the current LOR trend, repositories are moving from pre-publication reviews towards post-publication reviews based on a open community reviewers (Atkins et al., 2007).

The following tables present the dimensions of the framework. The selected characteristics include:

- Policy - usually set as an overall approach for the repository by the technology developer

- Technological - Automated technology \& services provided within the portal

- Social - Many quality approaches demand collaborative actions from the community making them quality co-creators

The following Tables 2-4 describe quality approaches their characteristic and the key references.

\begin{tabular}{|c|c|c|}
\hline \multicolumn{3}{|c|}{ LORQAF - Generic quality approaches } \\
\hline $\begin{array}{l}\text { Quality } \\
\text { approaches }\end{array}$ & Characteristics & References \\
\hline $\begin{array}{l}\text { Use of quality } \\
\text { standards such as } \\
\text { ISO } 9000\end{array}$ & Policy & $\begin{array}{l}\text { Manouselis et al., 2010; Stracke \& } \\
\text { Hildebrandt, 2007; Clements \& } \\
\text { Pawlowski, 2012; Ehlers \& Pawlowski, } \\
\text { 2006; Hirata, 2006; Abdellatief et al., } \\
\text { 2011; Wilson \& Town, 2006; Saarti et al., } \\
\text { 2010; Zschoke \& Beniest, 2010; Stracke } \\
\text { 2009; Ehlers et al., 2006 }\end{array}$ \\
\hline $\begin{array}{l}\text { Use of } \\
\text { Standardized } \\
\text { metadata }\end{array}$ & Technological & $\begin{array}{l}\text { Atenas \& Havemann, 2014; Barker and } \\
\text { Ryan 2003; Currier et al. 2004; Smith and } \\
\text { Casserly 2006; Wiley 2007; Wilson 2008; }\end{array}$ \\
\hline
\end{tabular}




\begin{tabular}{|l|l|}
\hline & Palavitsinis et al., 2013; Barton, Currier, \& \\
& Hey, 2003; Howarth, 2003; Moen, \\
& Stewart, \& McClure, 1998; Park, 2006; \\
& Wilson, 2007; \\
\hline
\end{tabular}

Table 2: Generic quality approaches

Many comprehensive reviews of quality approaches (such as Atenas \& Havemann., 2014 and Palavitsinis et al., 2013) on LOR quality only include quality instruments, which means that the generic approaches and the policy level of the repositories is considerably less researched than specific approaches and instruments. This might also be due to the complexity of standards like ISO 9000 (ISO, 2014). 24 papers from the years of 1998 to 2014 were identified to present generic quality approaches such as quality standards or using standardized metadata as the quality approach.

\begin{tabular}{|l|l|l|}
\hline \multicolumn{2}{|c|}{ LORQAF - TEL specific quality approaches } \\
\hline $\begin{array}{l}\text { Quality } \\
\text { approaches }\end{array}$ & Characteristics & References \\
\hline Expert review & Policy & $\begin{array}{l}\text { Atkins et al., 2007; Catteau et al, 2008; } \\
\text { Kurilovas, 2009; Sanz-Rodríquez et al., } \\
\text { 2010; Kumar et al., 2005; Westbrook et } \\
\text { al., 2012; Nielsen, 1994; Clements \& } \\
\text { Pawlowski, 2012; }\end{array}$ \\
\hline $\begin{array}{l}\text { Quality } \\
\text { benchmarking }\end{array}$ & Policy & $\begin{array}{l}\text { Atkins et al., 2007; Balagué \& Saarti, } \\
\text { 2009; Wilson \& Town, 2006; }\end{array}$ \\
\hline $\begin{array}{l}\text { Quality guideline } \\
\text { or criteria }\end{array}$ & Policy & $\begin{array}{l}\text { Leacock \& Nesbit, 2007; Babalhavaeji } \\
\text { et al., 2010; Sinclair et al, 2013; Vargo } \\
\text { et al., 2003; Defude \& Farhat, 2005; } \\
\text { Boskic, 2003; Kurilovas, 2009; } \\
\text { Westbrook et al., 2012; Babalhavaeji et } \\
\text { al., 2010; Dobratz et al., 2007 }\end{array}$ \\
\hline
\end{tabular}

Table 3 TEL Specific quality approaches

20 papers from 1994 to 2012 were identified to tackle the issue or specific quality approaches. Quality benchmarking seems to have been in fashion around 10 years ago, but the current 
approaches in quality assurance are moving towards specific quality instruments rather than checking the quality of the materials against criteria by experts. However, the lack of a powerful community to back up the collaborative instruments (Zervas et al., 2014), expert review would be a vital part in assuring the quality of the resources. 


\begin{tabular}{|c|c|c|}
\hline \multicolumn{3}{|c|}{ LORQAF - Specific Quality instruments } \\
\hline Quality approaches & Characteristics & References \\
\hline $\begin{array}{l}\text { Peer review/user ratings } \\
\text { (usually on likert scale } \\
1-5 \text { ) }\end{array}$ & $\begin{array}{l}\text { Technological, } \\
\text { Social }\end{array}$ & $\begin{array}{l}\text { Atenas \& Havemann, 2014; Larsen and } \\
\text { Vincent-Lancrin 2005; Schuwer et al. } \\
\text { 2010; Windle et al. 2010; Minguillon et } \\
\text { al., 2009; Stacey, 2007; Lefoe et al., } \\
\text { 2009; Catteau et al, 2008; Li, 2010; } \\
\text { Krauss \& Ally, 2005; Sanz-Rodríquez } \\
\text { et al., 2010; Sampson \& Zervas, 2013; } \\
\text { Currier et al, } 2004 \\
\text { Zervas et al., 2014;Liddy et al., 2002; } \\
\text { Waaijers \& van der Graaf, 2011; } \\
\text { Venturi \& Bessis, 2006; Zhang et al., } \\
\text { 2004 }\end{array}$ \\
\hline $\begin{array}{l}\text { User evaluation tools } \\
\text { (e.g. LORI) }\end{array}$ & $\begin{array}{l}\text { Technological, } \\
\text { Social }\end{array}$ & $\begin{array}{l}\text { Atenas \& Havemann, 2014; Clements } \\
\text { \& Pawlowski, 2012; Downes, 2007; } \\
\text { Richter \& Ehlers, 2010; Atkins et al., } \\
\text { 2007; Sinclair et al., 2013; Vargo et al., } \\
\text { 2003; Defude \& Farhat, 2005; Kumar et } \\
\text { al., 2005; Alharbi et al., 2011; }\end{array}$ \\
\hline $\begin{array}{l}\text { Recommender systems } \\
\text { (featured resources) }\end{array}$ & $\begin{array}{l}\text { Technological, } \\
\text { Social }\end{array}$ & $\begin{array}{l}\text { Manouselis et al, 2013; Atenas \& } \\
\text { Havemann, 2014; Pegler, 2012; Petrides } \\
\text { \& Nguyen 2008; Adomavicius \& } \\
\text { Tuzhilin 2005; Duffin \& Muramatsu, } \\
\text { 2008; Manouselis \& Sampson 2004; } \\
\text { Manouselis et al, 2011; Li, 2010; Sanz- } \\
\text { Rodríquez et al., 2010; Sabitha et al., } \\
\text { 2010; Sampson \& Zervas, 2013; Zervas } \\
\text { et al., 2014; }\end{array}$ \\
\hline Commenting & $\begin{array}{l}\text { Technological, } \\
\text { Social }\end{array}$ & $\begin{array}{l}\text { Minguillon et al., 2009; Catteau et al, } \\
\text { 2008; Li, 2010; Vargo et al., 2003; } \\
\text { Sanz-Rodríquez et al., 2010; Sampson } \\
\text { \& Zervas, 2013; Waaijers \& van der } \\
\text { Graaf, 2011; }\end{array}$ \\
\hline Favorites & $\begin{array}{l}\text { Technological, } \\
\text { Social }\end{array}$ & $\begin{array}{l}\text { Minguillon et al., 2009; Sanz-Rodríquez } \\
\text { et al., 2010; Sampson \& Zervas, 2013; } \\
\text { Zervas et al., 2014; }\end{array}$ \\
\hline
\end{tabular}




\begin{tabular}{|c|c|c|}
\hline Social tagging & $\begin{array}{l}\text { Technological, } \\
\text { Social }\end{array}$ & $\begin{array}{l}\text { Minguillon et al., 2009; Stacey, 2007; } \\
\text { Sampson \& Zervas, 2013; }\end{array}$ \\
\hline $\begin{array}{l}\text { Subscription (e.g. RSS- } \\
\text { feed) }\end{array}$ & Technological & $\begin{array}{l}\text { Minguillon et al., 2009; Sampson \& } \\
\text { Zervas, 2013; Zervas et al., 2014; }\end{array}$ \\
\hline $\begin{array}{l}\text { Flagging (reporting on } \\
\text { broken links, } \\
\text { inapproperiate content } \\
\text { etc.) }\end{array}$ & $\begin{array}{l}\text { Technological, } \\
\text { Social }\end{array}$ & $\begin{array}{l}\text { Sinclair et al., 2013; Clements \& } \\
\text { Pawlowski, } 2012\end{array}$ \\
\hline $\begin{array}{l}\text { Keywords of the } \\
\text { resources }\end{array}$ & Technological & $\begin{array}{l}\text { Atenas \& Havemann, 2014; Davis et al. } \\
\text { 2010; Richter and McPherson } 2012\end{array}$ \\
\hline $\begin{array}{l}\text { Multilingualism of the } \\
\text { repositories }\end{array}$ & Technological & $\begin{array}{l}\text { Atenas \& Havemann, 2014; OECD } \\
\text { 2007; Pawlowski and Hoel 2012; } \\
\text { UNESCO, } 2012\end{array}$ \\
\hline $\begin{array}{l}\text { Inclusion of } \\
\text { collaborative social } \\
\text { Media tools }\end{array}$ & $\begin{array}{l}\text { Technological, } \\
\text { Social }\end{array}$ & $\begin{array}{l}\text { Atenas \& Havemann, 2014; UNESCO } \\
\text { 2012; Minguillon et al., 2009; } \\
\text { Minguillon et al., 2009; Sampson \& } \\
\text { Zervas, 2013; Ehlers, 2004; }\end{array}$ \\
\hline $\begin{array}{l}\text { Specification of the } \\
\text { Authorship and IPR } \\
\text { (e.g. creative commons } \\
\text { licence }\end{array}$ & Policy & $\begin{array}{l}\text { Atenas \& Havemann, 2014; Bissell } \\
\text { 2009; Wiley, Bliss, and McEwen 2014; } \\
\text { Wiley and Gurrell 2009; Attwell, 2005; } \\
\text { Browne et al. 2010; Butcher, Kanwar, } \\
\text { and Uvalić-Trumbić 2011; Petrides et } \\
\text { al., } 2008\end{array}$ \\
\hline $\begin{array}{l}\text { Availability of the } \\
\text { source code or original } \\
\text { files }\end{array}$ & Technological & $\begin{array}{l}\text { Atenas \& Havemann, 2014; Atkins, } \\
\text { Brown, and Hammond 2007; Petrides et } \\
\text { al., 2008; Tuomi 2006; UNESCO 2011; } \\
\text { Currier et al, 2004; Ehlers, 2004; }\end{array}$ \\
\hline Trusted networks & Policy & $\begin{array}{l}\text { Davis et al., 2010; Pawlowski \& } \\
\text { Clements, 2013; }\end{array}$ \\
\hline Automatic testing of & Technological & Defude \& Farhat, 2005; Palavitsinis et \\
\hline
\end{tabular}




\begin{tabular}{|l|l|}
\hline metadata & $\begin{array}{l}\text { al., 2013; Kurilovas, 2009; Liddy et al., } \\
\text { 2002; Stvilia et al., 2002; Strong et al., } \\
\end{array}$ \\
& $1995 ;$
\end{tabular}

Table 4 Specific quality instruments

Total of 56 papers were identified to propose specific quality instruments for quality assurance of LORs. The timeline of these studies were published in between 1995 and 2014 . Most specific quality instruments have two dimensions: The technological and the social, collaborative characteristic. This means that the LOR developers code technological quality assurance features into the portal interface and then expect the users' to interact with the feature to provide evidence of quality for others in the same community. During this literature review, we identified the total of 15 different quality assurance approaches by specific quality instruments.

\section{Discussion}

Social interaction is considered to be the dominant factor affecting collaboration in groups (Kreijns et al., 2007). Specific quality instruments such as studied in this paper can increase social interaction and collaboration between users. In fact, the most cited quality approaches from the TEL literature seem to have been specific quality instruments: 'peer reviewing' and 'recommendation systems'. This clearly indicates that the future trend of repositories is not only moving towards facilitating collaborative interaction between users as Chatti et al., 2007 predicted but is doing so through quality assurance related specific instruments. Unfortunately, the mere existence of these features does not guarantee the repository to be successful. Ratings are an easy feature for repository developers to add, but this study does not go deeper into how much the users are actually rating content or commenting on them. These kinds of features work in the field of e-commerce where strong communities in web shops like eBay can show user ratings from masses and that actually contributes towards the user's perception of the quality of the object. However, in the field of education, users have different level of motivation in using quality assurance features and such repositories in general. Collaborative instruments alone cannot assure quality if there are no communities to back them up. As quantitative studies of LORs by Ochoa \& Duval (2009) and Zervas et al. 
(2014) noticed, there are very little repositories with actual user community strong enough to be working like a wikipedia to assure their quality through collaboration.

Based on this literature review, it is our recommendation that the LOR and CSCL environment developers would take a mixed approach for assuring their quality. Expert review might be not the most economical approach, but it seems to be needed in order to evaluate the substance of the resources in the repository. Once the community is strong enough, the user-generated collaborative quality instruments such as peer reviews, comments and rankings can be trusted more to assure the quality of the LORs and CSCL environments. LOR and CSCL developers should think of the quality assurance as a holistic approach:

1. What are the quality policies of the repository or environment?

2. Which quality assurance instruments can be automated?

3. Quality assurance before or after the resource is published?

4. Ensuring quality by paying external experts to review resources?

5. Which user-generated collaborative quality instruments we want to include?

6. What will be the most cost-efficient and sustainable quality assurance approach in the future?

It is our expectation that the LORQAF can be a useful tool when choosing the quality assurance approach for a learning repository or updating a previous one.

\section{Summary}

As the main contribution of this study, we constructed an LOR quality assurance framework (LORQAF) for LOR developers to take into consideration when building future repositories or updating the existing ones. Within the first part of the study, we analysed LOR quality literature within open and technology enhanced learning domains. Our analysis highlighted the state of the art and compiled a comprehensive overview of the most researched quality approaches, instruments and metrics. The framework is foreseen to be applied in qualitative studies that address LOR Quality approaches. It can also be utilized in quantitative approaches, such as incorporating it for studying LOR success eg. using the DeLone \& McLean IS success model (DeLone \& McLean, 1992; 2003). Our findings indicate that the 
future of LORs quality assurance relies heavily on collaborative instruments, which encourage users to participate in the co-creation of the CSCL environments. 


\section{References}

Abdellatief, M., Sultan, A. B., Jabar, M. A., \& Abdullah, R. (2011). A technique for quality evaluation of e-learning from developers perspective. American Journal of Economics and Business Administration, 3(1), 157.

Abelson, H. (2008). The creation of OpenCourseWare at MIT. Journal of Science Education and Technology, 17(2), 164-174.

Adomavicius, G.; Tuzhilin, A, "Toward the next generation of recommender systems: a survey of the state-of-the-art and possible extensions," Knowledge and Data Engineering, IEEE Transactions on , vol.17, no.6, pp.734,749, June 2005 doi: 10.1109/TKDE.2005.99

Alharbi, A., Henskens, F., \& Hannaford, M. (2011, December). Computer science learning objects. In e-Education, Entertainment and e-Management (ICEEE), 2011 International Conference on (pp. 326-328). IEEE.

Atenas, J., \& Havemann, L. (2014). Questions of quality in repositories of open educational resources: A literature review. Research in Learning Technology, 22. doi:10.3402/rlt.v22.20889

Atkins, D. E., Brown, J. S. \& Hammond, A. L. (2007) A Review of the Open Educational Resources (OER) Movement: Achievements, Challenges, and New Opportunities, The William and Flora Hewlett Foundation, [online] Available at: http://www.hewlett.org/uploads/files/ReviewoftheOERMovement.pdf

Attwell, G. (2005, July). What is the significance of open source software for the education and training community. In The First International Conference on Open Source Systems (OSS 2005), Genova, Italy, July 11 (Vol. 15).

Babalhavaeji, F., Isfandyari-Moghaddam, A., Aqili, S. V., \& Shakooii, A. (2010). Quality assessment of academic libraries' performance with a special reference to information technology-based services: Suggesting an evaluation checklist. Electronic Library, The, 28(4), 592-621.

Balagué, N., \& Saarti, J. (2009). Benchmarking quality systems in two European academic libraries. Library management, 30(4/5), 227-239.

Barker, E. \& Ryan, B. (2003) 'The higher level skills for industry repository', in Case Studies in Implementing Educational Metadata Standards (CETIS), eds. P. Barker \& E. Barker, [online] Available at: http://metadata.cetis.ac.uk/guides/usage_survey/cs_hlsi.pdf

Barton, J., Currier, S. \& Hey, J.M.N. (2003), "Building quality assurance into metadata creation: an analysis based on the learning objects and e-prints communities of practice", 
Proceedings 2003 Dublin Core Conference: Supporting Communities of Discourse and Practice Metadata Research and Applications (DC-2003), Seattle, WA, USA, 28 September-2 October 2003, available at: http://eprints.rclis.org/archive/00001972/ (accessed January 2007).

Bissell, A. N. (2009). Permission granted: open licensing for educational resources. Open Learning, 24(1), 97-106.

Boskic, N. (2003, July). Learning objects design: what do educators think about the quality and reusability of learning objects?. In Advanced Learning Technologies, IEEE International Conference on (pp. 306-306). IEEE Computer Society.

Browne, T. et al. (2010) 'The challenges of OER to academic practice', Journal of Interactive Media in Education, pp. 1-15, [online] Available at: http://wwwjime.open.ac.uk/jime/article/viewArticle/2010-3/html

Butcher, N. (2010) ‘OER dossier: open educational resources and higher education', Workshop for Heads of Commonwealth Universities, South Africa, [online] Available at: http://www.col.org/SiteCollectionDocuments/OER_Open_Educational_Resources_and_Higher_E ducation.pdf

Catteau, O., Vidal, P., \& Broisin, J. (2008, July). Learning Object Virtualization Allowing for Learning Object Assessments and Suggestions for Use. In Advanced Learning Technologies, 2008. ICALT'08. Eighth IEEE International Conference on (pp. 579-583). IEEE.

Cechinel, C., Sánchez-Alonso, S., \& García-Barriocanal, E. (2011). Statistical profiles of highly-rated learning objects. Computers \& Education, 57(1), 1255-1269.

Chatti, M. A., Jarke, M., \& Frosch-Wilke, D. (2007). The future of e-learning: a shift to knowledge networking and social software. International journal of knowledge and learning, 3(4), 404-420.

Clements, K. I., \& Pawlowski, J. M. (2012). User oriented quality for OER: Understanding teachers' views on re use, quality, and trust. Journal of Computer Assisted Learning, 28(1), 4-14.

Clements, K., Pawlowski, J., \& Manouselis, N. (2014). Why Open Educational Resources Repositories fail-Review of Quality Assurance Approaches. In EDULEARN14 Proceedings. 6th International Conference on Education and New Learning Technologies Barcelona, Spain (pp. 929-939). International Association of Technology, Education and Development IATED. ISBN 978-84-617-0557-3. International Association of Technology, Education and Development IATED.

Crnkovic, D. G. (2010). Constructive research and info-computational knowledge generation. In L. Magnani, W. Carnielli, \& C. Pizzi (Eds.). Proceedings of model based reasoning in science and technology abduction logic and computational discovery conference (Vol. 314).

Berlin/Heidelberg: Springer. 
Currier, S. et al. (2004) 'Quality assurance for digital learning object repositories: issues for the metadata creation process', ALT-J, Research in Learning Technology, vol. 12, no. 1, pp. 5-20. doi: 10.1080/0968776042000211494. Publisher Full Text

Davis, H. C., Carr, L., Hey, J. M., Howard, Y., Millard, D., Morris, D., \& White, S. (2010). Bootstrapping a culture of sharing to facilitate open educational resources. Learning Technologies, IEEE Transactions on, 3(2), 96-109.

DeLone, W.H., and McLean, E.R. (1992), "Information Systems Success: the quest for the dependent variable", Information Systems Research, 3(1), pp. 60-95.

DeLone, W.H., and McLean, E.R. (2003), "The DeLone and McLean Model of Information Systems Success: A Ten-Year Update", Journal of Management Information Systems (19:4), pp. 9-30.

Defude, B., \& Farhat, R. (2005, July). A framework to design quality-based learning objects. In Advanced Learning Technologies, 2005. ICALT 2005. Fifth IEEE International Conference on (pp. 23-27). IEEE.

Dichev, C., \& Dicheva, D. (2012, June). Is it time to change the OER repositories role?. In Proceedings of the 12th ACM/IEEE-CS joint conference on Digital Libraries (pp. 31-34). ACM.

Dillenbourg, P. (1999). What do you mean by collaborative learning?. Collaborative-learning: Cognitive and Computational Approaches., 1-19.

Dimitriadis, Y., McAndrew, P., Conole, G., \& Makriyannis, E. (2009). New design approaches to repurposing open educational resources for collaborative learning using mediating artefacts.

Dobratz, S., Schoger, A., \& Strathmann, S. (2007). The nestor catalogue of criteria for trusted digital repository evaluation and certification. Journal of Digital Information, 8(2).

Downes, S. (2001). Learning objects: resources for distance education worldwide. Review of Research in Open and Distance Learning, 2(1), 1

Downes, S. (2007) 'Models for sustainable open educational resources', Interdisciplinary Journal of Knowledge and Learning Objects, vol. 3, pp. 29-44.

Duffin, J., \& Muramatsu, B. (2008). OER recommender: Linking NSDL pathways and OpenCourseWare repositories. In Proceedings of the ACM International Conference on Digital Libraries (p. 449 -). doi:10.1145/1378889.1378994

European Foundation for Quality Management. (2014). EFQM Excellence Model, Ehlers, U. D. (2004). Quality in e-learning from a learner's perspective. European Journal for Distance and Open Learning.

Ehlers, U. D., \& Pawlowski, J. M. (2006). Quality in European e-learning: An introduction. In Handbook on quality and standardisation in e-learning (pp. 1-13). Springer Berlin Heidelberg. 
Ehlers, U. D., Goertz, L., Hildebrandt, B., \& Pawlowski, J. M. (2006). Quality in e-learning: use and dissemination of quality approaches in European e-learning: a study by the European Quality Observatory.

Ehlers, U. D., \& Pawlowski, J. M. (2006). Handbook on Quality and Standardisation in E-learning. Heidelberg: Springer.

Ehlers, U. D. (2009). Web 2.0-e-learning 2.0-quality 2.0? Quality for new learning cultures. Quality Assurance in Education, 17(3), 296-314.

Fink, A. (2005). Conducting Research Literature Reviews: From the Internet to Paper (2nd ed.). Thousand Oaks, California: Sage Publications.

Higher Education Founding Council for England. (2001). Quality assurance in higher education Proposals for consultation.

Hirata, K. (2006, July). Information model for quality management methods in e-Learning. In Advanced Learning Technologies, 2006. Sixth International Conference on (pp. 1147-1148). IEEE.

Hoyle, D. (2001). ISO 9000: quality systems handbook.

Howarth, L.C. (2003). Designing a common namespace for searching metadata-enabled knowledge repositories: An international perspective. Cataloging and Classification Quarterly, 37(1-2), 173185.

Hylén, J. (2006). 'Open educational resources: opportunities and challenges', Proceedings of Open Education, [online] Available at: http://library.oum.edu.my/oumlib/sites/default/files/file_attachments/odl-resources/386010/oeropportunities.pdf

ISO 9000 (2014), 'Quality Management Systems. Fundamentals and vocabulary', International Standards Organisation

Kitchenham, B. (2004). Procedures for performing systematic reviews. Technical Report Keele University TR/SE-0401 and NICTA 0400011T.1, Software Engineering Group, Department of Computer Science, Keele University.

Krauss, F., \& Ally, M. (2005). A study of the design and evaluation of a learning object and implications for content development. Interdisciplinary Journal of E-Learning and Learning Objects, 1(1), 1-22.

Kreijns, K., Kirschner, P. A., Jochems, W., \& Van Buuren, H. (2007). Measuring perceived sociability of computer-supported collaborative learning environments. Computers \& Education, 49(2), 176-192. 
Kumar, V., Nesbit, J., \& Han, K. (2005, July). Rating learning object quality with distributed bayesian belief networks: The why and the how. In Advanced Learning Technologies, 2005. ICALT 2005. Fifth IEEE International Conference on (pp. 685-687). IEEE.

Kurilovas, E. (2009, November). Learning Content Repositories and Learning Management Systems Based on Customization and Metadata. In Future Computing, Service Computation, Cognitive, Adaptive, Content, Patterns, 2009. COMPUTATIONWORLD'09. Computation World: (pp. 632637). IEEE.

Larsen, K. \& Vincent-Lancrin, S. (2005) 'The impact of ICT on tertiary education: advances and promises', Paper Presented at the OECD/NSF/U Michigan Conference 'Advancing Knowledge and the Knowledge Economy, 10-11 January 2005, Washington, DC.

Laurillard, D. (2008). Open teaching: The key to sustainable and effective open education. Opening up education: The collective advancement of education through open technology, open content, and open knowledge, 319-336.

Leacock, T. L., \& Nesbit, J. C. (2007). A framework for evaluating the quality of multimedia learning resources. Educational Technology \& Society, 10(2), 44-59.

Lefoe, G., Philip, R., O'Reilly, M., \& Parrish, D. (2009). Sharing quality resources for teaching and learning: A peer review model for the ALTC Exchange in Australia. Australasian Journal of Educational Technology, 25(1), 45-59.

Li, J. Z. (2010, September). Quality, evaluation and recommendation for learning object. Educational and Information Technology (ICEIT), 2010 International Conference on.

Liddy, E., Allen, E., Harwell, S., Corieri, S., Yilmazel, O., Ozgencil, N.,... (2002). Automatic metadata generation \& evaluation. In Proceedings of the 25th Annual International ACM SIGIR Conference on Research and Development in Information Retrieval (pp. 401-402). New York: ACM Press.X Manouselis, N., \& Sampson, D. (2004, August). Recommendation of quality approaches for the European Quality Observatory. In Advanced Learning Technologies, IEEE International Conference on (pp. 1082-1083). IEEE Computer Society.

Lipponen, L., Hakkarainen, K., \& Paavola, S. (2004). Practices and orientations of CSCL. In What we know about CSCL (pp. 31-50). Springer Netherlands.

Manouselis, N., Drachsler, H., Vuorikari, R., Hummel, H., \& Koper, R. (2011). Recommender systems in technology enhanced learning. In Recommender systems handbook (pp. 387-415). Springer US.

Manouselis, N, Jehad Najjar, Kostas Kastrantas, Gauri Salokhe, Christian M. Stracke, Erik Duval, Metadata interoperability in agricultural learning repositories: An analysis, Computers and Electronics in Agriculture, Volume 70, Issue 2, March 2010, Pages 302-320, ISSN 0168-1699, http://dx.doi.org/10.1016/j.compag.2009.07.007. 
Manouselis, N., Drachsler, H., Verbert, K., \& Duval, E. (2013). Recommender systems for learning (pp. 1-20). New York, NY: Springer.

Manouselis, N., Kyrgiazos, G., \& Stoitsis, G. (2014). Exploratory study of multi-criteria recommendation algorithms over technology enhanced learning datasets. Journal of e-Learning and Knowledge Society, 10(1).

McGreal, R. (2004). Learning objects: A practical definition. International Journal of Instructional Technology and Distance Learning, 1(9). Retrieved September 15, 2011 from http://www.itdl.org/Journal/Sep_04/article02.htm

McGreal, R. (2008). A typology of learning object repositories. In Handbook on information technologies for education and training (pp. 5-28). Springer Berlin Heidelberg.

McGreal, R. (2011) 'Open educational resource repositories: an analysis', The 3rd Annual Forum on e-Learning Excellence, Dubai, UAE, Dubai, [online] Available at: http://elexforum.hbmeu.ac.ae/Proceeding/PDF/OpenEducationalResource.pdf

Minguillón, J., Rodríguez, M. E., \& Conesa, J. (2010). Extending learning objects by means of social networking. In Advances in Web-Based Learning-ICWL 2010 (pp. 220-229). Springer Berlin Heidelberg.

Mitchell, S. M., \& Lutters, W. G. (2006, April). Assessing the value of computer science course material repositories. In Software Engineering Education and Training Workshops, 2006. CSEETW'06. 19th Conference on (pp. 2-2). IEEE.

Moen, W.E., Stewart, E., \& McClure, C.R. (1997). The role of content analysis in evaluating metadata for the U.S. Government Information Locator Service (GILS): Results from an exploratory study. Retrieved September 18, 2014 from http://www.unt.edu/wmoen/publications/GILSMDContentAnalysis.htm

Monge, S., Ovelar, R., \& Azpeitia, I. (2008). Repository 2.0: Social dynamics to support community building in learning object repositories. Interdisciplinary Journal of E-Learning and Learning Objects, 4(1), 191-204.

Nesbit, J., Belfer, K., \& Vargo, J. (2002). A convergent participation model for evaluation of learning objects. Canadian Journal of Learning and Technology/La revue canadienne de l'apprentissage et de la technologie, 28(3).

Neven F. \& Duval. E. (2002). Reusable learning objects: a survey of LOM-based repositories. In Proceedings of the tenth ACM international conference on Multimedia (MULTIMEDIA '02). ACM, New York, NY, USA, 291-294.

Nielsen, J. (1994, April). Usability inspection methods. In Conference companion on Human factors in computing systems (pp. 413-414). ACM. 
Nunamaker, J. F., Jr., Chen, M., \& Purdin, T. (1990). Systems development in information systems research. Journal of Management Information Systems, 7(3).

Ochoa, X. \& Duval, E. (2009). Quantitative Analysis of Learning Object Repositories, IEEE Transactions on Learning Technologies, 2 (3), 226-238.

OECD, 2007, "Giving knowledge for free: The emergence of open educational resources," [http://www.oecd.org/dataoecd/35/7/38654317.pdf]

Okada, A., Mikroyannidis, A., Meister, I., \& Little, S. (2012). “Colearning”-collaborative networks for creating, sharing and reusing OER through social media.

Palavitsinis, N., Manouselis, N., \& Sánchez-Alonso, S. (2013). METADATA QUALITY ISSUES IN LEARNING REPOSITORIES.

Park, J.R. (2006). Semantic interoperability and metadata quality: An analysis of metadata item records of digital image collections. Knowledge Organization, 33(1), 20-34.

Pawlowski, J.M. (2007). The Quality Adaptation Model: Adaptation and Adoption of the Quality Standard ISO/IEC 19796-1 for Learning, Education, and Training, Educational Technology \& Society, 10 (2).

Pawlowski, Jan M., and Kati I. Clements. "Implementing quality standards for knowledge-intensive organizations." Journal of Technology, Instruction, Cognition and Learning (TICL) 7 (2010): 295314.

Pawlowski, J.M. \& Clements, K.I (2013) Trusted Educational Networks for Internationalization of Open Educational Resources, International Journal for Innovation and Quality in Learning (INNOQUAL), Volume 1, Issue 1. (2013), ISSN: 2294-9763

Pawlowski, J. \& Hoel, T. (2012) Towards a Global Policy for Open Educational Resources: The Paris OER Declaration and its Implications. White Paper, Version 0.2, Jyväskylä, [online] Available at: http://monet.informatik.rwth-aachen.de/giotto/OpenScout_df6f1252-bfa6-11e1-a668e13baff9bd23.pdf

Pawlowski, J. M., \& Zimmermann, V. (2007). Open content: a concept for the future of e-learning and knowledge management. Proc. of Knowtech, Frankfurt.

Pegler, C. (2012). 'Herzberg, hygiene and the motivation to reuse: towards a three-factor theory to explain motivation to share and use OER', Journal of Interactive Media in Education, no. 1968, pp. 118, [online] Available at: http://jime.open.ac.uk/2012/04

Pérez-Mateo, M., Maina, M. F., Guitert, M., \& Romero, M. (2011). Learner generated content: Quality criteria in online collaborative learning. European Journal of Open, Distance and ELearning. 
Petrides, L., Nguyen, L., Jimes, C. \& Karaglani, A.. (2008) 'Open educational resources? inquiring into author use and reuse', International Journal of Technology Enhanced Learning, vol. 1, pp. 98 117. Publisher Full Text

Pirkkalainen, H., \& Pawlowski, J. (2014, June). Collaborating on ideas: Tackling barriers to open education. In World Conference on Educational Multimedia, Hypermedia and Telecommunications (Vol. 2014, No. 1, pp. 1844-1852).

Pirkkalainen, H., Jokinen, J., Pawlowski, J. M., \& Richter, T. (2014b). Overcoming Cultural Distance in Social OER Environments. In CSEDU 2014: Proceedings of the 6th International Conference on Computer Supported Education: Vol. 1. Edited by S. Zvacek, M. Restivo, J. Uhomoibhi, \& M. Helfert. SCITEPRESS-Science and Technology Publications. ISBN 978-989-758-020-8. SCITEPRESS-Science and Technology Publications.

Retalis, S. (2005). Usable and interoperable e-learning resources repositories. IDEA GROUP PUBLISHING, 249.

Richter, T. \& Ehlers, UD. (2010) 'Barriers and motivators for using open educational resources in schools', Open ED 2010 Proceedings, Barcelona, pp. 1-12, [online] Available at: http://www.icde.org/filestore/Resources/OPAL/RichterEhlersBarriersandMotivatorsforUsingOERinSchools.pdf

Saarti, J., Juntunen, A., \& Taskinen, A. (2010). Multi-faceted measuring of the quality as a tool for quality improvement in the Kuopio University Library, Finland. Performance measurement and metrics, 11(1), 39-46.

Sabitha, A. S., Mehrotra, D., \& Bansal, A. (2012, May). Quality metrics a quanta for retrieving learning object by clustering techniques. In Digital Information and Communication Technology and it's Applications (DICTAP), 2012 Second International Conference on (pp. 428-433). IEEE.

Sampson, D. G., \& Zervas, P. (2013). Learning object repositories as knowledge management systems. Knowledge Management \& E-Learning: An International Journal (KM\&EL), 5(2), 117 136.

Sánchez-Alonso, S., Sicilia, M. A., García-Barriocanal, E., Pagés-Arévalo, C., \& Lezcano, L. (2011). Social models in open learning object repositories: A simulation approach for sustainable collections. Simulation Modelling Practice and Theory, 19(1), 110-120.

Sanz-Rodriguez, J., Dodero, J. M., \& Sánchez-Alonso, S. (2010). Ranking learning objects through integration of different quality indicators. Learning Technologies, IEEE Transactions on, 3(4), 358-363.

Schuwer, R. et al. (2010) 'Production of OER? a quest for efficiency', 7th Annual Open Education Conference, Barcelona, [online] Available at: http://openaccess.uoc.edu/webapps/o2/handle/10609/5103 
Sinclair, J., Joy, M., Yau, J. K., \& Hagan, S. (2013). A practice-oriented review of learning objects. Learning Technologies, IEEE Transactions on, 6(2), 177-192.

Stacey, P. (2007). Open educational resources in a global context. First Monday, 12(4).

Stracke, C. M. (2009). Quality Development and Standards in e-Learning: Benefits and Guidelines for Implementations. In Proceedings of the ASEM Lifelong Learning Conference: e-Learning and Workplace Learning. ASEM, Bangkok.

Stracke, C. M., \& Hildebrandt, B. (2007, June). Quality Development and Quality Standards in e Learning: Adoption, Implementation, and Adaptation. In World Conference on Educational Multimedia, Hypermedia and Telecommunications (Vol. 2007, No. 1, pp. 4158-4165).

Strong, D. M., Lee, Y. W., \& Wang, R. Y. (1997). Data quality in context. Communications of the ACM, 40(5), 103-110.

Stvilia, B., Gasser, L., Twidale, M. B., Shreeves, S. L., \& Cole, T. W. (2004). Metadata quality for federated collections.

Tate, M., \& Hoshek, D. (2009). A Model for the Effective Management of Re-Usable Learning Objects (RLOs): Lessons from a Case Study. Interdisciplinary Journal of E-Learning and Learning Objects, 5(1), 51-72.

Tuomi, I. (2006) 'Open educational resources: what they are and why do they matter report prepared for the OECD', [Online] Available at:

http://www.meaningprocessing.com/personalPages/tuomi/articles/OpenEducationalResources_OE CDreport.pdf

Tzikopoulos A., Manouselis N. \& Vuorikari R. (2007). An overview of learning object repositories. In Proceedings of Northrup (Ed.), Learning Objects for Instruction: Design and Evaluation, Idea Group Inc.

UNESCO. (2002) 'Forum on the impact of Open Courseware for higher education in developing countries final report', [Online] Available at: http://unesdoc.unesco.org/images/0012/001285/128515e.pdf

UNESCO. (2011) Guidelines for Open Educational Resources (OER) in Higher Education, UNESCO - COL, Paris.

UNESCO. (2012) '2012 Paris OER Declaration', 2012 World Open Educational Resources (OER) Congress, Paris, June 2012, United Nations Educational, Scientific and Cultural Organization, Paris, [online] Available at: http://www.unesco.org/new/index.php?id=64395

Vargo, J., Nesbit, J. C., Belfer, K., \& Archambault, A. (2003). Learning object evaluation: computermediated collaboration and inter-rater reliability. International Journal of Computers and Applications, 25(3), 198-205. 
Venturi, G., \& Bessis, N. (2006). User-centred evaluation of an e- learning repository. In Proceedings of the 4th Nordic conference on Human-computer interaction: changing roles (pp. 203-211).

ACM.

Waaijers, L., \& van der Graaf, M. (2011). Quality of research data, an operational approach. D-Lib magazine, 17(1/2).

Westbrook, R. N., Johnson, D., Carter, K., \& Lockwood, A. (2012). Metadata clean sweep: a digital library audit project. D-Lib Magazine, 18(5/6).

Wiley, D., Bliss, T. J. \& McEwen, M. (2014) 'Open educational resources: a review of the literature', Handbook of Research on Educational Communications and Technology, pp. 787-794, Available at: http://link.springer.com/chapter/10.1007/978-1-4614-3185-5_63

Wiley, D., \& Edwards, E. (2002). Online self-organizing social systems. Quarterly Review of Distance Education, 3(1), 33.

Wiley, D. \& Gurrell, S. (2009) 'A decade of development...', Open Learning: The Journal of Open and Distance Learning, vol. 24, no. 1, pp. 11-21. doi: 10.1080/02680510802627746.

Wilson, A.J. (2007). Toward releasing the metadata bottleneck: A baseline evaluation of contributorsupplied metadata. Library Resources \& Technical Service, 51(1), 16-28.

Wilson, T. (2008) 'New ways of mediating learning: investigating the implications of adopting open educational resources for tertiary education at an institution in the United Kingdom as compared to one in South Africa', International Review of Research in Open and Distance Learning, vol. 9, no. 1 , pp. 1-19.

Wilson, F., \& Town, J. S. (2006). Benchmarking and library quality maturity. Performance measurement and metrics, 7(2), 75-82.

Windle, R. et al. (2010) 'Sharing and reuse in OER: experiences gained from open reusable learning objects in health', Journal of Interactive Media in Education, pp. 1-18, [online] Available at: http://jime.open.ac.uk/jime/article/viewArticle/2010-4/html

Zervas, P., Alifragkis, C., \& Sampson, D. G. (2014). A quantitative analysis of learning object repositories as knowledge management systems. Knowledge Management \& E-Learning: An International Journal (KM\&EL), 6(2), 156-170.

Zhang, Y., Jeng, J., \& Li, Y. (2004, November). IFLA FRBR as user-centred metadata evaluation framework for moving image collections. In Proceedings of the American Society for Information Science and Technology, annual meeting.

Zschocke, T., \& Beniest, J. (2011). Adapting a quality assurance framework for creating educational metadata in an agricultural learning repository. Electronic Library, The, 29(2), 181-199. 